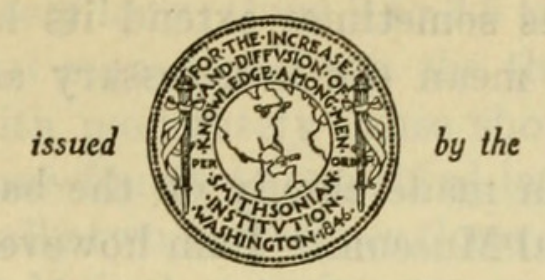

SMITHSONIAN INSTITUTION

U. S. NATIONAL MUSEUM

\title{
A REVIEW OF THE LARVAEVORID FLIES OF THE TRIBE LESKIINI WITH THE SETULOSE FIRST VEIN $\left(\mathbf{R}_{1}\right)$
}

\section{By Maurice T. James}

IN SPITE of the fact that certain of them are actually or potentially important parasites of agricultural pests, the tachina flies of the tribe Leskiini have been neglected by taxonomists. No comprehensive treatment of the species has ever been published. The writer had undertaken a study of the genera and species of the New World, but, seeing that its completion would require more time than he had at his disposal, he decided to limit it to the group here under discussion, namely, to those genera in which the first vein $\left(R_{1}\right)$ is setulose to or practically to the apex. So far as known, no Old World genus possesses this character.

Townsend, ${ }^{1}$ after keying out on another basis a genus which does not concern us, uses the setulose first vein as the first major division of his tribe Leskiini. In this section he places seven genera, of which six, including two that I am reducing to synonymy, form a closely related complex. The seventh genus, Spathipalpus Rondani, is probably not a leskiine; at any rate, its relationship to the other six is quite distant. Since Townsend has placed it in this tribe, I am including it in the generic key, though omitting it from the body of the work.

The terminology used in this paper is basically that used by Townsend; some modifications are made for the purpose of increased clarity. All measurements were made by a micrometer scale; in some cases these differ radically from those stated in the original descrip-

${ }^{1}$ Manual of myiology, pt. 4, p. 65, 1936. 
tions, thus demonstrating the fallacy of making measurements by eye. In measuring the haustellum I have taken only its corneous portion; the membranous parts sometimes extend its length slightly, but to measure them would mean the unnecessary addition of a variable element.

This study has been made chiefly on the basis of material in the United States National Museum. I am however, indebted also to the following individuals and institutions for the loan of small, though valuable, collections: Dr. H. J. Reinhard, Texas Agricultural Experiment Station; A. R. Brooks, Division of Entomology, Ottawa, Ontario; and Dr. C. H. Curran, American Museum of Natural History.

As limited above, this complex of genera will trace with relative ease through Townsend's ${ }^{2}$ complicated keys to the families and tribes of Oestroidea. In the family key the genera ${ }^{3}$ will run to couplet 47 , page 12 ; in the key to the tribes of Dexiidae, they run to couplet 4, page 27. The characters which, according to Townsend's Manual, may be considered diagnostic of the group under consideration, may, therefore, be summarized as follows:

Head not swollen. Cheeks distinct, at least one-eighth eye length. Antennal arista thin, with short to medium pubescence. Epistoma of moderate width, slightly to moderately warped forward, distinctly shorter than clypeus. Proboscis once geniculated; corneous part of haustellum at least half head height, slender, often bowed or curved, set with scattered to rather dense, erect, short setulae. Frontal bristles moderately strong, at least one on each side placed below base of antenna; hind reclinate, frontoorbitals not closely approximated to the verticals; ocellars present though sometimes weak, proclinate, divaricate. Prosternum ${ }^{4}$ and propleura bare; tympanic ridge bare; thorax without plumose hairs. Pteropleural bristle shorter than the sternopleurals. Abdomen 4-segmented, ovate, not "wasplike"; tergites covering ventral membrane and larger parts of sternites.

In addition to the above, this group of genera may be characterized as follows: Form moderately slender. Head from lateral view trapezoidal, its length at oral margin at least 0.8 , sometimes equal to, that at base of antennae; front gently sloping, flat to moderately convex, its length equal to or slightly less than that of face; clypeus not or but slightly depressed, 1.25 to 1.50 as high as its maximum width, without a facial carina; parafacials bare, two to three times as wide at base of antennae as at narrowest point; vibrissae strong, each surrounded

\footnotetext{
${ }^{2}$ Manual of myiology, pt. 3, 1936.

${ }^{3}$ Proleskiomima, in which the prosternum is provided with hairs and bristles, is an exception; it will trace to couplet 33 , page 10.

${ }^{4}$ See footnote 3.
} 
by a few setulae, rarely by several short bristles; facials otherwise bare. Eyes bare or practically so. First segment of antenna short, erect; second moderately long; third 2 to 3.5 times as long as second; arista with both basal segments short, the third slender, somewhat thickened basally, with moderately dense short hair to tip. Postocellar bristles small, one-fourth to one-third length of inner verticals, the latter strong; usually two, sometimes three or four, gnathoorbitals.

Transverse suture distinct, crossing mesonotum at or somewhat before middle. Presutural acrosticals present or absent; one postsutural (prescutellar) acrostical; two or three presutural dorsocentrals; three postsutural dorsocentrals; no posthumeral; usually one preintraalar, the hind one, when present, being weak; three (rarely two) postintraalars; one, sometimes two, presupraalars; three postsupraalars, the middle one especially strong; intrapostalar absent or extremely weak; two postalars, the hind one especially strong; normally three sternopleurals. Wing 0.40 to 0.45 as wide as long; cell $\mathbf{R}_{5}$ narrowly open or rarely short-petiolate, ending not more than length of cross vein $r-m$ from wing tip; vein $R_{1}$ with setulae extending to its apex, or at most with one or two apical setulae missing; vein $\mathbf{R}_{5}$ setulose approximately to cross vein $r-m$, the setulae ending sometimes slightly before, sometimes slightly beyond that point; stem vein (base of radius, or the remigium or Townsend's terminology) bare; vein $R_{5}$ bowed down apically; cubitulus gently rounded and without a stump; apical section of $\mathrm{Cu}_{1}$ short; cross vein $\mathrm{r}-\mathrm{m}$ half to three-fifths the distance from $r-m$ to the cubitulus.

Abdomen short; ovate; first segment with a pair of lateral bristles, with or without a pair of median marginals; second segment with one or more pairs of laterals; third and fourth each with a marginal row; no discals on any segment. Male genitalia small, anal forceps broad basally, with a narrowly tapered slender point; both anterior and posterior claspers present; aedeagus short and rather slender.

In coloration the species conform to a fairly uniform pattern. The body is either actually predominantly yellow or apparently so as a result of the dense pollinosity which obscures the areas of black background on the head and thorax. Each half of the mesonotum has two longitudinal vittae formed from brownish to black pollen; the inner one, located between the dorsocentral and acrostical rows, is narrow, from one to three times as wide as the diameter of a trichopore of a dorsocentral bristle; it is not interrupted at the suture and may reach the anterior margin of the mesonotum; the outer and much broader one, located between the dorsocentral and intraalar rows, is distinctly separated by pale-pollinose areas from both the anterior and the posterior margin of the mesonotum, and is broadly interrupted at the suture. The abdomen is yellow in background, with black markings. 
KEY TO THE GENERA

1. Palpus approximately as long as third antennal segment and extending beyond oral margin, if at all, by a distance not greater than length of second antennal segment; vertex at least one-third head width

Palpus usually 1.3 to 2 times length of third antennal segment and extending beyond oral margin by a distance usually twice or more the length of second antennal segment; if palpus is but little longer than third antennal segment, vertex less than one-fifth head width

2. Prosternum bare; frontalia approximately as wide as a parafrontal; lateral postscutellar plates bare; tergites mainly shining dorsally_-_-_-_-_- 3

Prosternum bristled at sides ; frontalia approximately width of combined parafrontals; each lateral postscutellar plate with a tuft of setulae; tergites pollinose dorsally

1. Proleskiomima

3. Haustellum cylindrical, not noticeably constricted on apical half, at most three-fourths head height; outer verticals prominent; male without proclinate frontoorbitals and with elongated tarsal claws_

2. Leskiella

Haustellum strongly constricted on approximately penultimate fourth, at least almost head height; outer verticals absent or indistinguishable from postocular setulae; males and females alike with two proclinate frontoorbitals and with short tarsal claws

3. Leskiomima

4. Costal spine strong; front noticeably flattened; three proclinate frontoorbitals ; three frontals below antennal bases

Spathipalpus

Costal spine rudimentary; front at least slightly convex; at most 2 proclinate frontoorbitals, except as an abnormal condition; one or two frontals below antennal bases

5. Vertex about one-third head width, that of male slightly narrower than that of female; male and female alike with two proclinate frontoorbitals and with short claws 4. Dejeaniopalpus

Vertex not more than two-sevenths, usually one-fourth to one-sixth head width, and much narrower in male than in female; male without frontoorbitals and with elongated claws

5. Genea

\section{Genus PROLESKIOMIMA Townsend}

Proleskiomima TownseNd, Rev. Ent., vol. 4, pp. 395-396, 1934; Manual of myiology, pt. 4, p. 65, 1936 ; pt. 9, pp. 234-235, 1939.

Female (male unknown).-Head 0.6 as long and 1.25 as wide as high. Front flat in profile; vertex 0.4 head width; frontalia broad, about twice maximum width of a parafrontal; epistoma in clypeal plane; parafacial at base of antenna fully three times as wide as at narrowest part; facials approximately in clypeal plane, each with a few very short setulae and two or three short bristles near vibrissa; cheek 0.2 eye height. Haustellum in type specimen partly withdrawn, but apparently about half head height; straight, cylindrical, becoming somewhat smaller in diameter toward apex; labella small; palpus spatulate, slightly bowed, approximately as long as third antennal segment, with two or three outstanding setulae near apex below. Third antennal segment three times as long as second. Lateral postscutellar plates each with a tuft of short black hairs between halter and base of 
squama. Hind tarsus two-thirds as long as its tibia. Cell $\mathbf{R}_{5}$ narrowly open; vein $R_{1}$ with setulae approximately evenly spaced and extending to its apex.

Chaetotaxy.-Postocellars slightly divergent; outer verticals strong, 0.8 as long as inner verticals; ocellars weak; two proclinate and two reclinate frontoorbitals, almost in a line with the frontals; two strong frontals, anterior one below base of antennae. Three feebly developed, yet distinct, presutural acrosticals; three presutural dorsocentrals; two humerals; two lateroscutellars; no apicoscutellars; one discoscutellar placed far back and approaching position of an apicoscutellar; two small bristles and several fine hairs in a pteropleural tuit; two hypopleurals; two small bristles and several hairs laterally on the prosternum. Second abdominal segment with strong median marginals.

\section{PROLESKIOMIMA FRONTALIS Townsend}

Proleskiomima frontalis Townsend, Rev. Ent., vol. 4, p. 396, 1934.

Length, $5.5 \mathrm{~mm}$. Head with ground color of parafrontals and of occiput above level of lower eye margins black, of frontalia orange, otherwise yellow; densely covered with pollen which is for the most part whitish, that of frontalia, however, golden, and that of vertex and upperpart of occiput brownish yellow; parafrontals with scattered black hairs ending opposite anterior frontals; a few minute black setulae around each vibrissa. Antenna yellow, third segment brownish; second segment at apex above and third on upper surface with black setulae. Palpus with a few black hairs below, otherwise with short black setulae. Proboscis brownish, labella yellow, erect hairs of haustellum black, those of labella brownish. Postocular hairs black above, whitish on lower third; occipital vestiture, except a few hairs on each side above, whitish.

Ground color of mesonotum and scutellum blackish, of pleura yellowish, becoming brownish on pteropleura and metapleura; pollen whitish on pleura, becoming light golden on mesopleura and pteropleura, and brownish yellow on mesonotum; mesonotal vittae broad, the inner in width two to three times diameter of a trichopore of a dorsocentral bristle. Coxae and trochanters yellow; hind femur and tibia yellow, becoming brownish apically; hind tarsus blackish, the segments becoming yellow toward their apices. Hairs of mesonotum, scutellum, coxae, and hing legs black, moderately dense; those of pleura of same color, but sparse. Wing lightly infuscated; squamae whitish; halteres yellow.

Abdomen mainly reddish yellow; segment 1 narrowly brownish toward median line dorsally; segments 2 to 4 largely blackish in ground color on dorsal surface of tergites, second and third each with a broad 
reddish-yellow basal triangle on each side, fourth broadly reddish yellow laterally; abdomen with dense yellowish pollen forming a somewhat tessellated pattern but not, however, obscuring the background.

Holotype.-Female, Itaquaquecetuba, São Paulo, Brazil, June 1, U.S.N.M. No. 57287.

The description is based on the type, the only specimen known to me. It is in good condition except that one antenna and the artista of the other one are missing, and the legs, except one hind one, are broken off beyond the trochanters. Townsend described the arista as "long as antenna and micro pubescent" and the legs as "fulvous, tarsi dark."

\section{LESKIELLA, new genus}

Front moderately convex; width of frontalia at middle subequal to or a little less than that of a parafrontal; vertex one-third head width in female, two-sevenths in male; epistoma slightly warped; parafacial twice as wide at base of antennae as at narrowest point; cheek onefourth to one-third eye height. Haustellum 0.60 to 0.75 head height, straight, cylindrical, and approximately of equal diameter throughout, none of its setulae arising from pigmented pores; labella small; palpus bowed, subequal to third antennal segment in length in the female but shorter in the male, with one or two outstanding setulae ventrally at about three-fourths its length. Third antennal segment 3 to 3.5 as long as second; aristal hairs approximately equal in length to basal diameter of arista. Lateral postscutellar plates bare. Tarsi somewhat longer than tibiae; claws in female short, in male longer than fourth or fifth tarsal segment. Wing with cell $R_{5}$ narrowly open; vein $\mathbf{R}_{1}$ with setulae approximately evenly spaced and extending not quite to tip, usually one or two of the apical setulae missing.

Chaetotaxy.-Postocellars not decussate; outer verticals clearly differentiated, more prominent in the female, one-half to one-third length of inner verticals; ocellars moderately strong, two proclinate and one small reclinate frontoorbitals in the female, no proclinate and one small reclinate frontoorbital in the male; six to eight frontals, the anterior two small, the first distinctly below, the second slightly below and almost level with, the antennal bases, the first sometimes duplicated. Presutural acrosticals absent or one or two pairs moderately developed and distant from suture; 2 presutural dorsocentrals ; hind preintraalar wanting; two, rarely, three, humerals; two postalars; usually three lateroscutellars, the intermediate pair set close to the hind one, usually weak but distinctly stronger than surrounding hairs, the hind pair convergent but not decussate; one discoscutellar; no apicoscutellars; one moderately small pteropleural; four or five hypopleurals. No median marginals on first and second abdominal segments.

Genotype.-Leskiella brevirostris, new species. 
LESKIELLA BREVIROSTRIS, new species

Figure $3, b$

Length, 4 to $6 \mathrm{~mm}$. Occiput on upper third or half black; head otherwise yellow in ground color. Pollen of frontalia yellow, scattered, showing best from front view; that of parafrontals yellow; that of rest of head whitish with a yellowish tinge. Parafrontals bare or with a few scattered fine black hairs; a few black setulae of varying size around each vibrissa. Antenna yellow, the third segment with an

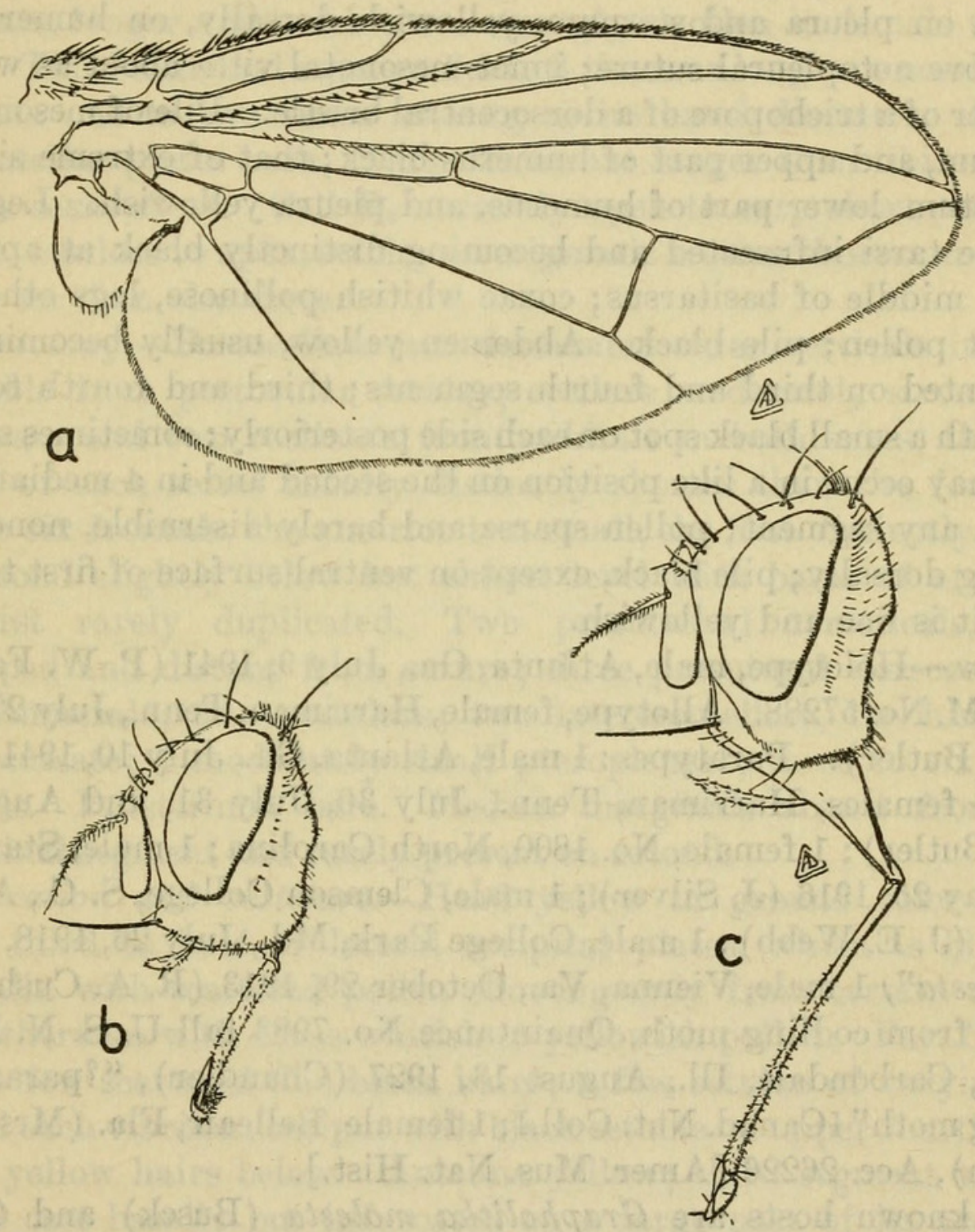

Figure 3.- $a$, Leskiomima tenera (Wiedemann), wing; b, Leskiella brevirostris, new species, head, lateral view; c, Leskiomima tenera (Wiedemann), head, lateral view.

orange cast basally, largely infuscated on apical half or more, the infuscation extending almost to the arista dorsally, darker and more extensive from an inner than from an outer aspect; first segment dorsally and second segment dorsally and apically with a few black hairs; arista yellow, becoming somewhat infuscated on apical half or 
less; hairs concolorous. Proboscis yellow; haustellum on apical third and labella reddish yellow; erect hairs of haustellum and labella black with some yellow intermixed. Palpus, aside from the preapical setulae, with some fine black hairs ventrally and with scattered short, sharp setulae. Occipital vestiture black on upper fourth, otherwise soft, yellow.

Thorax dull black in ground color, except humeri, sides of mesonotum, scutellum, propleura, upperparts of mesopleura, and other pleural areas of varying extent along the sutures, which are yellow; pollen whitish on pleura and sternum, yellowish dorsally, on humeri, and just above notopleural suture; inner mesonotal vitta about as wide as diameter of a trichopore of a dorsocentral bristle. Pile of mesonotum, scutellum, and upper part of humerus black; that of extreme sides of mesonotum, lower part of humerus, and pleura yellowish. Legs yellow, the tarsi infuscated and becoming distinctly black at approximately middle of basitarsus; coxae whitish pollinose, legs otherwise without pollen; pile black. Abdomen yellow, usually becoming orange-tinted on third and fourth segments; third and fourth tergites each with a small black spot on each side posteriorly; sometimes similar spots may occur in a like position on the second and in a median position on any segment; pollen sparse and barely disernible, none of it showing dorsally; pile black, except on ventral surface of first tergite, where it is fine and yellowish.

Types.-Holotype, male, Atlanta, Ga., July 9, 1941 (P. W. Fattig), U.S.N.M. No. 57288. Allotype, female, Harriman, Tenn., July 27, 1933 (H. G. Butler). Paratypes: 1 male, Atlanta, Ga., July 10, 1941 (Fattig) ; 3 females, Harriman, Tenn., July 30, July 31, and August 2, 1933 (Butler) ; 1 female, No. 1800, North Carolina; 1 male, Staunton, Va., May 25, 1916 (J. Silver) ; 1 male, Clemson College, S. C., August 7, 1931 (J. E. Webb) ; 1 male, College Park, Md., July 26, 1918, "from L. molesta"; 1 male, Vienna, Va., October 29, 1913 (R. A. Cushman), reared from codling moth, Quaintance No. 7983 [all U. S. N. M.]; 1 female, Carbondale, Ill., August 13, 1927 (Chandler), "?parasite of codling moth" [Canad. Nat. Coll.]; 1 female, Belleair, Fla. (Mrs. A. T. Slosson), Acc. 26226 [Amer. Mus. Nat. Hist.].

The known hosts are Grapholitha molesta (Busck) and Carpocapsa pomonella (Linnaeus).

\section{Genus LESKIOMIMA Brauer and Bergenstamm}

Leskiomima Brautr and Bergenstamm, Denkschr. Akad. Wiss. Wien, vol. 58, p. 372, 1891 ; vol. 60, p. 133, 1893.-Coquillett, U. S. Dept., Agr., Div. Ent., Tech. Bull. 7, p. 67, 1897.-Townsend, Rev. Mus. Paulista, vol. 15, p. 211, 1926 ; Manual of myiology, pt. 4, p. 65, 1936; pt. 9, pp. 224-225, 1939. (Genotype, Stomoxys tenera Wiedemann, monobasic.)

Lesciomima Brauer and Bergenstamm, Denkschr. Akad. Wiss. Wien., vol. 58, p. 372, 1891 (lapsus). 
Front slightly convex; vertex a little more than one-third head width, not significantly different in the two sexes; width of frontalia slightly less than that of a parafrontal; epistoma in clypeal plane; parafacial twice as wide at base of antennae as at narrowest point; cheek one-fourth to one-third eye height. Haustellum at least almost head height, very slightly bowed, cylindrical on basal half, then gently constricted and gradually enlarging again toward apex, on apical half pigmented and with setulae arising from pigmented pores; labella small; palpus bowed, approximately as long as third antennal segment, spatulate, longer and much more strongly swollen in female than in male. Third antennal segment 2.5 to 3 times as long as second; hairs of arista one to two times as long as its basal diameter. Lateral postscutellar plates bare. Tarsi somewhat longer than tibiae; claws in both sexes short. Cell $R_{5}$ narrowly open to very short-petiolate; vein $R_{1}$ setulose to apex, setulae on stigmatic section shorter and more closely set than elsewhere.

Chaetotaxy.-Postocellars not decussate; outer verticals indistinguishable from postocular setulae; ocellars moderately strong; two proclinate and two reclinate frontoorbitals in both sexes, the hind bristle of each series usually distinctly shorter than the fore one; four to six frontals, the anterior two small, the first distinctly below, the second slightly below but almost level with bases of antennae, the first rarely duplicated. Two presutuaral acrosticals, welldeveloped and distant from suture; three presutural dorsocentrals; three humerals; two postalars; two lateroscutellars, the hind pair not decussate; 1 moderately small pteropleural; three to six hypopleurals. Prosternum bare. Median marginals absent from first abdominal segment and rarely present on second.

Coloration and vestiture.-Head yellow in ground color except upper third to half of lateral occipital plates, which is blackish. Frontalia with scattered pollen showing only from certain angles; bead otherwise with dense whitish to yellowish pollen. Parafrontals with a few scattered fine black hairs; a few setulae of varying size around each vibrissa; occiput with black setulae on upper fourth, with softer yellow hairs below. Antenna yellow; third segment with an orange cast basally but infuscated on a large part of its area, the infuscation darker and more extensive from an outer than from an inner aspect. Proboscis yellow, apical third to half of haustellum and the labella brownish; erect hairs of haustellum rather dense, short, one-third to one-half as long as diameter of haustellum; labella with a few scattered black and yellow hairs. Palpi yellow, with scattered short, spinelike black setulae above and a few fine black hairs and one or more preapical setulae below.

Thorax dull black in background, except humeri, propleura, and certain other pleural areas, which are yellow; each inner mesonotal

$734132-47-2$ 
vitta about as wide as the diameter of a trichopore of a dorsocentral bristle; mesonotum except laterally, upper part of humerus, and scutellum black setulose, thorax otherwise with softer yellow hairs. Squamae and halteres yellow. Legs mainly yellow; tarsi, however, either entirely black or infuscated apically and appearing black under low magnification by virtue of the density of their black setulae; coxae whitish pollinose, legs otherwise without pollen; coxae mainly and posteroventral surface of middle and hind femora on basal part yellowish pilose, legs otherwise with black setulae.

Abdomen yellow, usually orange-tinged or infuscated on apical segments, and more or less marked with black, blackish, or brown; third and fourth tergites white-pollinose at base ventrally and laterally, this pollen showing from dorsal aspect at least as small posterior triangles laterally on the segments; ventral portions of first tergite with soft yellow pile, abdomen otherwise with rather dense black setulae.

\section{KEY TO THE SPECIES OF LESKIOMIMA}

1. Haustellum 1 to 1.25 times head height; one pair of discoscutellars ${ }^{\circ}$ and no apicoscutellars

Haustellum 1.5 times head height; no discoscutellars; one pair of small parallel apicoscutellars australis Townsend

2. Black ground color of thorax extended to include sides of mesonotum and base of scutellum; pollen of head and thorax entirely whitish to cinereous

cinerea, new species

Sides of mesonotum and entire scutellum yellow in ground color; parafrontals and mesonotum with yellow pollen tenera (Wiedemann)

\section{LESKIOMIMA AUSTRALIS Townsend}

Leskiomima australis Townsend, Rev. Chilena Hist. Nat., vol. 32, p. 368, 1928; Manual of myiology, pt. 9, p. 225, 1939.

Male.-Length, $6 \mathrm{~mm}$. Lateral occipital plates blackish on upper third; pollen of head mainly whitish, becoming yellow on parafrontals, upper third of occipital orbits and lateral occipital plates, area surrounding cheek groove, and narrow inner margin of parafacial. Infuscated area of third antennal segment reaching almost to base dorsally and to basal third ventrally; first segment of arista yellow, second and base of third infuscated, the third otherwise yellow on its basal third to half, beyond that black; hairs of arista concolorous. Haustellum about 1.5 times head height. Palpus below with one longer seta near apex and one at beginning of apical fourth. Five frontals.

Thorax with humeri, scutellum, sides of mesonotum, propleura, upper parts of mesopleura, and other pleural areas of varying extent

\footnotetext{
5 In rare instances the discoscutellars are set back rather far and may be confused with apicoscutellars.
} 
along suture, yellow in background; tarsi yellowish basally. No discoscutellars; 1 apicoscutellar, small, convergent.

Abdomen with a broad median vitta, broadly interrupted at bases of segments, extending from apex of segment 1 to middle of segment 4 ; a pair of large black spots on middle of segment 3 laterally and appearing as triangles from either dorsal or ventral aspect, the entire figure, if integument were spread out in a plane, being diamondshaped; small brownish connections between lateral markings and median vitta; apex of abdomen beyond these spots brownish yellow, the apical part of the vitta not very clearly apparent. Third and fourth tergites narrowly pollinose at base dorsally as well as ventrally.

Holotype.-Male, Itaquaquecetuba, São Paulo, Brazil, U.S.N.M. No. 57289.

The above description was based on the type, the only specimen of this species which I have seen. In the original description, the type was erroneously stated to be a female; for a possible explanation of this, see discussion under Leskiomima tenera (Wiedemann), page 103.

LESKIOMIMA CINEREA, new species

Length, $5 \mathrm{~mm}$. Lateral occipital plates blackish on upper half; pollen of head whitish with a slightly yellowish cast, that of parafrontals not noticeably different from that of rest of head. Haustellum 1 to 1.25 times head height. Third segment of antenna with infuscated area, from outer aspect, extending from apex almost to arista dorsally and about halfway ventrally; arista in male entirely black, in female with the first segment and the basal half of the third segment, beyond its thickened portion, yellow; hairs of arista concolorous with background. Palpus pale yellow; one or two stronger ventral setulae near apex and a longer one about one-third distance from the apex. Five frontals.

Thorax with humeri, broad apical and lateral margins of scutellum, propleura, and mesopleura immediately below anterior spiracles, yellow; thoracic pollen cinereous. Hind tarsi black. One discoscutellar; no apicoscutellars.

Abdomen orange-yellow; a subquadrate brownish median spot at apex of segment 1 ; in the female, this is followed by indefinitely bordered brownish areas forming a median vitta that reaches to apex of segment 3 , briefly interrupted at bases of segments, and expanding on segments 2 and 3 into complete posterior margins dorsally; in the male these areas are more reduced and form median triangles on about the apical two-thirds each of segments 2 and 3 and round spots at the bases of the marginal bristles of segment 3 .

Types.-Holotype, male, Orlando, Fla., January 1930 (D. J. Nicholson), on Erechtites heiracifolia, U.S.N.M. No. 57290. Allotype, female, Orlando, Fla., January 15, 1930 (Nicholson), on T'riphasia trifolia. 
Figure 3, $a, c$

Stomoxys tenera WiEdemann, Aussereuropaische zweiflügelige Insekten, vol. 1, p. 251, 1830.

Leskiomima tenera (Wiedemann) Brauer and Bergenstamm, Denkschr. Akad. Wiss. Wien, vol. 58 , p. 372,1891 ; vol. 60 , p. 133, 1893.-CoquilLetT, U. S. Dept. Agr., Div. Ent., Tech. Bull. 7, p. 67, 1897 (partim).-Sмгтн, Rep. New Jersey State Mus. for 1909, p. 777, 1910.-JoHnson, Bull. Amer. Mus. Nat. Hist., vol. 32, p. 71, 1913 ; vol. 41, p. 436, 1919.-Britton, Connecticut State Geol. and Nat. Hist. Surv. Bull. 31, p. 191, 1920.-Greene, Proc. U. S. Nat. Mus., vol. 60, p. 21, fig. 42, 1922 (puparium described and illustrated).-GILL, U. S. Dept. Agr. Farmers' Bull. 1364, p. 23, 1924.-ALDRICH, Ann. Ent. Soc. Amer., vol. 18, p. 121, 1925.-Johnson, Boston Soc. Nat. Hist. Occ. Papers, vol. 7, p. 190, 1925.-Gowder, Dept. Agr. Jamaica Ent. Bull. 4, pt. 1, p. 81, 1926.WEST, in Leonard, Cornell Univ. Agr. Exp. Stat. Mem. 101, p. 810, 1928.Aluen, Ann. Ent. Soc. Amer., vol. 22, p. 683, 1929.-Haeussler, Journ. Agr. Res., vol. 41, p. 367, 1930 (misidentification?).-TownSEND, Rev. Ent., vol. 1, p. 90, 1931.-BRImLeY, Insects of North Carolina, p. 359, 1938.

Leskiomera tenera (Wiedemann) BANks, Ent. News, vol. 23, p: 110, 1912 (lapsus).

Length, 5.5 to $7.5 \mathrm{~mm}$. Lateral occipital plates black on upper third; pollen of head whitish for the most part, yellowish, however, on parafrontals, upper third of occipital orbits and of occiput, areas surrounding cheek groove, and inner margin of parafacial. Third antennal segment with infuscated area, from outer aspect, extending from apex almost to arista dorsally and about halfway ventrally; first segment of arista yellow; second and base of third infuscated, the third otherwise yellow on its basal third or half, its apical part black; aristal hairs concolorous with background. Haustellum 1 to 1.25 times head height. Palpus with two or three longer preapical ventral setulae. Four to six frontals.

Thorax with humeri, scutellum, sides of mesonotum, propleura, upper parts of mesopleura and other pleural areas of varying extent, yellow in background. Tarsi more or less yellow basally. One discoscutellar; no apicoscutellars.

Abdomen with segments 3 and 4 somewhat orange-tinged and with small black spots on sides posteriorly; somewhat similar spots may occur in a like position on segment 3 and in a medioapical position on any tergite.

Type.-Female, in the Natural History Museum in Vienna. In the original description, Wiedemann gave no type locality; Aldrich and Townsend, who later examined the type, stated that it bears an elaborate capital F in script, "Coll. Winthem" and "Type."

The known geographical distribution of this species extends from Nova Scotia and Quebec to Florida, Illinois, and Texas. It has been recorded in literature from New Hampshire, Massachusetts, Connecticut, New York, New Jersey, Pennsylvania, Maryland, District of 
Columbia, Virginia, North Carolina, Mississippi, and Illinois. Additional records that will extend its range beyond those previously published are Ohio; Berthierville, Quebec, July 2 to 9, 1940 (L. Daviault) ; Petite Rivière, Nova Scotia, August 9, 1936 (J. McDunnough) ; Charlotte, Maine, July 12, 1933; Opelousas, La., April 1897; Kerrville, Tex., April 12, 1907; College Station, Tex., April to November (H. J. Reinhard).

Records from Jamaica may apply to this or to another species. Curran ${ }^{6}$ recorded it from British Guiana as Myobia (Leskiomima) tenera Wiedemann, but his statement, "The first vein is bare, the third with two or three bristles basally," shows clearly that the record is based on a misidentification. Some of the records for states listed above may be based on misidentifications, although all are within the range of the species as indicated by specimens I have examined.

Adults have been collected on the flowers of Ceanothus by Banks. Larvae have been reared from the following hosts, all Lepidoptera: Desmia funeralis (Hübner) at Washington, D. C. (J. F. Strauss) ; Carpocapsa pomonella (Linnaeus) at Carbondale, Ill.; and Acrobasis juglandis (LeBBaron) (A. nebulella auctt., not Riley) at Monticello, Fla. (J. B. McGill), and Wiggins, Miss. (Allen, 1929), the latter record, according to Allen, being under circumstances which would cast some doubt upon the host relationship. Haeussler (1930) recorded it as a parasite of Grapholitha molesta (Busck), but a specimen in the United States National Museum, upon which this record may have been based, is Leskiella brevirostris James.

Both Aldrich and Townsend mistook the males of Leskiella for those of Leskiomima tenera. Aldrich ${ }^{7}$ says of Leskiomima that "the male has long claws and pulvilli, and has no orbitals," and Townsend ${ }^{8}$ makes use of the same characters in his generic description. This failure to associate the sexes properly may have been responsible for Townsend's error in describing the male of Leskiomima australis as a female. The male genitalia are small, but are apparent as such even when unspread.

\section{Genus DEJEANIOPALPUS Townsend}

Dejeaniopalpus Townsend, Proc. U. S. Nat. Mus., vol. 51, p. 312, 1916; Rev. Mus. Paulista, vol. 15, p. 212, 1927; Manual of myiology, pt. 4, p. 65, 1936, and pt. 9, pp. 214-215, 1939. (Genotype, Dejeaniopalpus texensis Townsend, monobasic.)

Genea Rondani (partim), ALDRICH, Ent. News, vol. 35, pp. 210-214, 1924.

Dejeaniopsis JoHnson, Proc. Boston Soc. Nat. Hist., vol. 7, p. 190, 1925 (lapsus).

Front moderately convex, vertex about one-third head width, slightly less in the male; frontalia as wide as average width of a parafrontal;

Bull. Amer. Mus. Nat. Hist., vol. 66, p. 508, 1934.

${ }^{7}$ Ent. News, vol. 35, p. 211, 1924.

Manual of myiology, pt. 9, pp. 224-225, 1939. 
epistoma distinctly warped; cheek 0.22 to 0.30 eye height. Haustellum 0.8 to 1.5 head height; labella small; palpus bowed, spatulate, 1.5 to 1.75 as long as third antennal segment, when in normal position extending one-third to one-half its length beyond oral margin. Third antennal segment two to three times as long as second, its length twice to three times width. Lateral postscutellar plates bare. Tarsi longer than tibiae; claws in both sexes short. Wing with cell $\mathbf{R}_{5}$ narrowly open; $\mathbf{R}_{1}$ with setulae to apex, those in the stigmatic section more closely set than elsewhere.

Chaetotaxy.-Outer verticals well-developed in both sexes; ocellars moderately strong, normally two proclinate frontoorbitals, hind one somewhat the weaker; one strong and sometimes one weak reclinate frontoorbital; five to eight frontals, of which one or two weak ones are located distinctly below and one almost opposite and slightly below, antennal base. Presutural acrosticals sometimes absent, more commonly one or two pairs present and remote from suture; 3 presutural dorsocentrals; hind preintraalar absent or weak; three humerals; two lateroscutellars, with sometimes an adventitious third; no apicoscutellars, except abnormally; discoscutellars absent, or one or two weak pairs present; one short pteropleural; three to five hypopleurals; three, rarely two, sternopleurals. Prosternum bare.

Coloration and vestiture.-Head mainly yellow in ground color. Pollen of frontalia sparse, whitish, distinguishable only from front view; that of head otherwise dense, yellowish above, more or less whitish below. Parafrontalia bare or with a few scattered black hairs; a few black setulae of varying size on facial near vibrissa. First and second antennal segments with short black setulae dorsally and apically. Palpi yellow, clothed with scattered, very short, sharp, black setulae. Thorax black and yellow in ground color, with dense whitish to yellowish pollen; black hairs on dorsum, with black and soft yellow hairs laterally. Squamae and halteres yellow. Legs yellow, tarsi more or less blackish or brown; coxae with whitish pollen, legs otherwise without pollen. Abdomen black-haired above, with black and soft yellow hairs below.

\section{KEYS TO THE SPECIES OF DEJEANIOPALPUS}

1. Haustellum slender, 1.5 times as long as head height; hairs of arista distinctly longer than its maximum diameter tenuirostris, new species

Haustellum moderately robust, not so long as head height; hairs of arista no longer than its maximum diameter

2. Antenna of moderate size, the third segment being about 0.45 head height; palpus of female swollen; mesopleura yellow in ground color; abdomen largely yellow, the segments with black markings, which are at least narrowly isolated from those on adjoining segments; first abdominal segment with median marginals 3

Antenna rather small, the third segment being about 0.35 head height; palpus not swollen in either sex ; mesopleura largely black in ground color ; abdomen 
with a continuous black vitta running from base to apex, or largely black; first abdominal segment without median marginals; parafacial about twice as wide at base of antenna as at narrowest point_-- brasiliensis Townsend

3. Black spots of abdomen small and inconspicuous, the median ones on segments 2 and 3 usually not more than one-third length of respective segment; parafacial almost or quite three times as wide at base of antenna as at narrowest point texensis Townsend

Black spots of abdomen conspicuous, the median ones on segments 2 and 3 almost reaching base of respective segment; parafacial about twice as wide at base of antenna as at narrowest point__-__-_ longipalpis (Van der Wulp)

\section{DEJEANIOPALPUS TENUIROSTRIS, new species}

Length, $7 \mathrm{~mm}$. Minimum width of parafacial about two-fifths that at base of antennae. Vertex about two-sevenths head width. Lateral occipital plates blackish on upper two-fifths. Pollen of head yellow on parafrontals, whitish with a yellowish tinge elsewhere; pile of occiput concolorous with background. Antenna yellow; third segment with an orange cast basally, otherwise infuscated, more extensively outwardly than inwardly, the infuscated area reaching almost to arista dorsally and about halfway to the base ventrally; length of third segment about 0.45 head height, 0.55 length of palpus, and 2.8 length of second; arista yellow, becoming infuscated on its thinner portion, its hairs 1.5 to 2 times its maximum diameter. Proboscis chiefly yellow, apical half of haustellum and labella brownish; haustellum 1.5 head height, slender, attenuated on apical half. Palpus yellow, slender but as thick as the haustellum, with two outstanding apical setulae and one or two ventral ones on apical third; length of palpus about 0.8 head height. One reclinate frontoorbital.

Thorax yellow in background, the mesonotum except broad lateral margins and the base of the scutellum, however, blackish; inner mesonotal vitta about as wide as the trichopore of a dorsocentral bristle. Two presutural acrosticals; anterior presutural supraalar present but weak; 1 discoscutellar, set well toward apex of scutellum. Tarsi mainly blackish, the bases of the front and middle basitarsi, however, yellowish; hair of coxae and some hair at bases of femora soft, whitish, remaining hair of legs coarse, black. Wing with cross vein r-m opposite middle of stigma; part of vein $M_{1}$ beyond cubitulus distant from posterior margin of wing by less than half minimum width of cell $R_{s}$.

Abdomen yellow, becoming somewhat orange-tinged toward apex; second segment with a rounded black spot medially on apical third and a small black spot at apex on each side; third segment with a triangular median black spot on the apical half; third and fourth segments each with a prominent rounded black spot at apex on each side. Pile of first tergite ventrally mostly soft, whitish; abdomen otherwise clothed with coarse, black hairs. Ventral aspect of tergites with a trace of scattered, whitish pollen. 
Holotype.-Male, Tapachula, Mexico, August 17-19, 1943 (F. M. Snyder), American Museum of Natural History.

\section{DEJEANIOPALPUS BRASILIENSIS Townsend}

Dejeaniopalpus brasiliensis Townsend, Rev. Chilena Hist. Nat., vol. 32, p. 368, 1928.

Length, 6.5 to $7.5 \mathrm{~mm}$. Head mainly yellow, upper half of occiput, ocellar triangle, and parafrontals above anterior reclinate frontoorbitals black; pollen yellowish on upper part of occiput and on parafrontals, otherwise whitish; occiput with black hairs above, soft yellow pile below. Width of parafacial at narrowest point about half that at base of antenna. Antenna largely orange yellow, third segment, however, blackish beyond arista ; third segment 2.5 as long as second in male, 2.0 in female, about 0.35 height of head and 0.6 length of palpus; arista yellow on first and second segments, blackish on third, its hairs about as long as its maximum diameter. Proboscis with rostrum brown, haustellum yellow, becoming brown toward apex, and labella brown; haustellum about 0.9 head height, straight, cylindrical, somewhat attenuated on penultimate fourth, with short black erect hairs, labella with one or two long black hairs at apex, otherwise with yellowish hairs. Palpus alike in both sexes, 0.6 as long as height of head, no thicker than haustellum; one or two outstanding setulae near apex ventrally and an especially long one, about twice maximum diameter of palpus, at or beyond middle ventrally; a few soft black hairs below at base. Two reclinate frontoorbitals, the posterior one small.

Ground color of thorax black, that of humeri, propleura, and scutellum except base yellow; pollen yellow on mesonotum and humeri, whitish on pleura; inner mesonotal vitta definitely wider than diameter of a trichopore of a dorsocentral bristle. Anterior presutural supraalar present but weak; two relatively strong presutural acrosticals; no discoscutellars. Tarsi brownish to black; anterior surface of coxae with soft yellow hair, legs otherwise with coarse black hair. Cross vein $\mathbf{r}-\mathrm{m}$ opposite last fourth of stigma; part of vein $\mathbf{M}_{1}$ beyond cubitulus distant from posterior margin by three-fourths or more width of cell $R_{5}$.

Abdomen in the male yellow, somewhat darker on last two segments, with a median black vitta about as wide as distance between hind lateroscutellars or, on intermediate segments, somewhat broader, running from base of first almost to extreme apex of fourth segment; large lateral black spots on segments 3 and 4, a smaller one on segment 2, and brownish indications of one on segment 1 ; intermediate segments with margins of tergites next to sternites brownish; in the female these markings are expanded so that the median vitta and narrow posterior border of segment 1 , the dorsal aspect of the following tergites 
except a small area on each side of segment 2 basally, the broad apices of segments 3 and 4 ventrally, and the inner margins, next to the sternites, of tergites 2 to 4 ventrally, are black. Bases of segments 2 to 4 , dorsally and ventrally, with dense, whitish pollen, the areas broader and more conspicuous in the female; abdomen otherwise shining. No median marginals on segment 1.

Types.-Male, Itaquaquecetuba, São Paulo, Brazil, November 20, on flowers of Cordia curassavica; female, same locality, September 15, on foliage. The male is here designated the lectotype, U.S.N.M. No. 57291.

The description is based on the types.

\section{DEJEANIOPALPUS TEXENSIS Townsend}

Dejeaniopalpus texensis Townsend, Proc. U. S. Nat. Mus., vol. 51, p. 312, 1916; Manual of myiology, pt. 4, p. 65, 1936; pt. 9, p. 214, 1939.

Leskiomima tenera (Wiedemann) Coquilletr, U. S. Dept. Agr., Div. Ent., Tech. Bull. 7, p. 67, 1897 (partim) (not Wiedemann).

Genea texensis (Townsend) ALDRICH, Ent. News, vol. 35, pp. 212-213, 1924.JoHnson, Boston Soc. Nat. Hist. Occ. Papers, vol. 7, p. 190, 1925; Biological survey Mount Desert region, I, Insect fauna, p. 199, 1927.-West, in Leonard, Cornell Univ. Agr. Exp. Stat. Mem. 101, p. 810, 1928.-Рвостов, Biological survey Mount Desert region, IV, Insect fauna, p. 377, 1938.

Length, 4.5 to $7 \mathrm{~mm}$. Parafacial narrow below, minimum width one-third that at base of antenna. Lateral occipital plates blackish on upper two-fifths. Pollen of head yellow on parafrontals, whitish with a yellowish tinge elsewhere; pile of occiput concolorous with background. Antenna yellow; third segment with an orange cast basally, otherwise infuscated, more extensively outwardly than inwardly, the infuscated area outwardly reaching almost to arista dorsally and about halfway to the base ventrally; length of third segment about 0.45 head height, 0.67 length of palpus, and 2.5 to 3 times length of second; arista yellow, becoming somewhat infuscated on approximately apical half, its hairs concolorous and about as long as its maximum diameter. Proboscis yellow, labella reddish yellow; a few long blackish and yellowish hairrs at apex of haustellum and on labella; haustellum about 0.8 head height, straight, cylindrical, somewhat attenuated on penultimate fourth. Palpus yellow; three or four outstanding setulae at apex and one or two on ventral surface of apical half; length of palpus 0.65 to 0.70 head height; in the female enlarged on apical three-fifths, with maximum diameter greater than that of haustellum; in the male slightly enlarged, its maximum diameter subequal to that of haustellum. One reclinate frontoorbital.

Thorax yellow in background, the mesonotum except broad lateral margins and the base of the scutellum, however, blackish; lower pleural sclerites sometimes darkened in the middle; inner mesonotal vitta about 
as wide as the diameter of a trichopore of a dorsocentral bristle. Presutural acrosticals absent or one or two weak pairs present; anterior presutural supraalar weak or absent; one or two weak discoscutellars; scutellum sometimes with adventitious bristles. Tarsi beyond basitarsus blackish brown; ventral and posteroventral surfaces of femora and anterior surface of coxae with soft yellowish pile; legs otherwise black-haired. Wing with cross vein r-m usually opposite middle of stigma; part of vein $\mathbf{M}_{1}$ beyond cubitulus distant from posterior margin of wing by less than half maximum width of cell $R_{5}$.

Abdomen yellow, usually becoming orange-tinged on third and fourth segments; second and third segments medially and usually second to fourth segments laterally each with a small brownish to blackish spot; abdomen with thin whitish pollen below and none above. A pair of small median marginals on first segment. Pile on ventral surface of first tergite soft, yellow; hair of abdomen otherwise black.

Holotype.-Female, Texas, U.S.N.M. No. 20039.

The known distribution of this species extends from Quebec to Virginia and Texas. It has been recorded in literature from Maine, Vermont, Connecticut, New York, Pennsylvania, Virginia, and Texas; there are also specimens in the United States National Museum from Maryland and the District of Columbia. I have also seen specimens from Abbotsford, Quebec, July 29 (G. Shewell), Canadian National Collection.

This species has been reared from an unidentified leaf roller on Helianthus at Arendtsville, Pa., August 20,1927, by S. W. Frost; from "Botys sp."; and from Desmia funeralis (Hübner) at Cape Henry, Va., by August Busck, and at Washington, D. C., Quaintance No. 5542.

\section{DEJEANIOPALPUS LONGIPALPIS (Van der Wulp), new combination}

Myobia longipalpis VAN DER WULP, Biologia Centrali-Americana, Diptera, vol. 2, p. $138,1890$.

Genea longipalpis (Van der Wulp) ALDRICH, Ent. News, vol. 30, p. 214, 1924.

Until a male can positively be referred to this species, its generic status must remain somewhat uncertain. I have seen only a female, in the United States National Museum, which was determined as this species by both Townsend and Aldrich. It agrees with the original description, so far as that goes, and, though no mention is made of certain essential characters, I assume that the determination is correct. The characters, as nearly as can be judged from the female, are those of Dejeaniopalpus rather than of Genea. The vertex is 0.31 the head width. My description of $D$. texensis will apply to this specimen, with the exceptions indicated in the key.

Types.-Two females, from Chilpancingo, Guerrero, Mexico, presumably in the British Museum (Natural History). 
The above remarks were based on one female San Rafael, Veracruz, Mexico, March 8 (Townsend).

\section{Genus GENEA Rondani}

Genea Rondani, Nuovi Ann. Sci. Nat. Bologna, ser. 3, vol. 2, pp. 172-174, 1850.Aldrich, Ent. News, vol. 25, pp. 210-214, 1924.-Townsend, Rev. Mus. Paulista, vol. 15, p. 212, 1927 ; Manual of myiology, pt. 4, p. 65, 1936; pt. 9, pp. 218-219, 1939. (Genotype, Genea maculiventris Rondani, monobasic.)

Geneopsis Townsend, Rev. Mus. Paulista, vol. 15, p. 212, 1927; Manual of myiology, pt. 4, p. 65, 1936; pt. 9, pp. 221-222, 1939 . (Genotype, Geneopsis major Townsend, monobasic. New synonymy.)

Geneoglossa Townsend, Rev. Ent., vol. 5, p. 225, 1935; Manual of myiology, pt. 4 , p. 65,1936 ; pt. 9 , pp. $220-221,1939$. (Genotype, Geneoglossa glossata Townsend, monobasic, New synonymy.)

A careful study of these three genera, including the holotypes of the type species of the two reduced to synonymy, reveals no differences that might be considered generic. In his key to the Leskiini, Townsend uses the length of the haustellum, the strength of the ocellars, and size of the squamae, the presence or absence of median marginals on the first abdominal segment, and the length of the front tarsus of the female, as bases for his separation. It is significant that these are all relative characters, and when they are measured with a micrometer the supposed differences become smaller or vanish.

The following characters are shared by all members of the genus known to me:

Front moderately convex; vertex one-fourth to two-sevenths head width in female, one-fifth to one-sixth in male; frontalia as wide as average width of a parafrontal; clypeus distinctly warped forward; cheek one-fifth to one-fourth eye height. Third antennal segment 2.7 to 3.3 as long as second and 2.5 to 3.5 as long as its maximum width; hairs of arista somewhat longer than maximum aristal diameter. Lateral postscutellar plates bare. Tarsi longer than tibiae; claws in female short, in male elongated. Cell $\mathbf{R}_{5}$ narrowly open. Vein $\mathbf{R}_{1}$ with setulae to apex, those on stigmatal area sometimes more closely set.

Chaetotaxy.--Inner verticals decussate; outer verticals in female (except in gracilis, new species) well-developed and one-half to two-thirds length of inner verticals, in male sometimes differentiated, but weak; ocellars weak, frontoorbitals lacking in male, two proclinate and one or two reclinate in female; six to nine frontals, the anterior two or three below antennal bases. Two presutural acrosticals; three presutural dorsocentrals; hind presutural intraalar sometimes present, though weak; three humerals; two lateroscutellars; one to three discoscutellars, the hind pair placed well back and almost in the position of an apicoscutellar; no true apicoscutellars; one pteropleural; two to seven hypopleurals. 


\section{KEY TO THE SPECIES OF GENEA}

1. Third abdominal segment with a transverse black band, which occupies at least its posterior fourth, usually its posterior third to half; haustellum at least as long as head height

Third abdominal segment with a median posterior black spot, but without a complete cross band

2. Robust species; median marginals on first and second abdominal segments; palpus 1.7 to 2.0 length of third antennal segment; outer verticals clearly differentiated major (Townsend)

Slender species; no median marginals on either first or second abdominal segment; palpus about 1.3 length of third antennal segment; outer verticals hardly differentiated. gracilis, new species

3. Haustellum about 0.75 head height, cylindrical and straight; pollen of mesonotum deep yellow, almost golden aurea, new species

Haustellum at least head height, attenuated and gently curved backward on apical half; pollen of mesonotum with more of a whitish cast

4. Haustellum not more than 1.3 head height trifaria (Wiedemann)

Haustellum about 1.5 to 1.6 head height glossata (Townsend)

\section{GENEA MAJOR (Townsend), new combination}

Geneopsis major Townsend, Rev. Mus. Paulista, vol. 15, p. 311, 1927; Manual of myiology, pt. 4, p. 65, 1936 ; pt. 9, p. 221, 1939.

Length, 8 to $9 \mathrm{~mm}$. Head in ground color yellow except lateral occipital plates, which are blackish on approximately upper half; pollen brownish on frontalia, golden on parafrontals, pale yellowish on face and occiput. Hairs of parafrontals black, very sparse; those of upper half of occiput black, of lower half pale yellow. Outer verticals present in both sexes. Antenna yellow, third segment infuscated except on basal two-fifths ventrally and inwardly; arista brownish yellow, blackish on its thinner part, the hairs concolorous. Haustellum cylindrical, distinctly constricted on apical half, most slender on penultimate fourth, about 1.1 head height; color yellowish, becoming brownish toward apex. Palpus 1.75 (in female) to 2.0 (in male) length of third antennal segment; setulae black.

Mesonotum, except humeri and sides, and certain pleural areas of variable extent, black in ground color, the black strongly obscured by pollen but tending to show through more noticeably than in some other members of this and related genera; pollen of mesonotum, scutellum, and upper parts of pleura golden, of rest of thorax pale yellow to whitish; inner vitta of mesonotum somewhat broader than diameter of a trichopore of a dorsocentral bristle. Hairs of mesonotum, scutellum, and upperparts of humeri coarse, black, those of lower parts of humeri and pleura rather fine, yellowish. Legs yellow, tarsi blackish; coxae whitish pollinose, legs otherwise without pollen; some whitish hairs on coxae and at base of posteroventral surface of femora, legs otherwise black-haired. Wings hyaline; $R_{1}$ with setulae on 
stigmatal area more closely set than elsewhere. Squamae and halteres yellow.

Abdomen with a median black vitta extending from near base of first to apex of fourth segment, very narrowly interrupted at anterior margins of segments, on third segment broadening into a transverse band that occupies about apical third to half of dorsal surface of tergite; sides of segments 2 and 4 with black spots posteriorly which on segment 2 and perhaps also on segment 4 may be united with the median vitta. Most of hairs of segment 1 ventrally, and some also on segment 2 ventrally, yellowish, those of rest of abdomen black.

Types.-Male, Itaquaquecetuba, São Paulo, Brazil, October 26; female, Itaquaquecetuba, November 20 . The male is here designated the lectotype, U.S.N.M. No. 57294.

The description is based on the types, on a female, Itaquaquecetuba, São Paulo, Brazil, May 25 (C. H. T. Townsend), and on a male, Villarica, Paraguay, November 1936 (F. Schade).

GENEA GRACILIS, new species

Length, 5 to $7 \mathrm{~mm}$. Head in ground color yellow except lateral occipital plates, which are blackish on approximately upper half; pollen brownish on frontalia, golden on parafrontals, pale yellowish on face and occiput. Each parafrontal with a few scattered fine black hairs; occiput largely with fine yellow hair but with some coarser black hair above, more in the female than in the male. Outer verticals not differentiated in either sex. Antenna yellow, third segment infuscated except on basal third ventrally and inwardly; third segment rather slender; arista yellow on first two segments and thickened part of third, except its base, third otherwise brown; hairs unusually long for this genus, being about three times maximum diameter of arista. Haustellum slender, cylindrical, constricted on apical half, very slightly bowed backward, 1.3 to 1.5 head height; color yellow, brownish to blackish on apical half. Palpus about 1.3 length of third antennal segment; setulae black, mostly short, 1 outstanding preapical and 1 outstanding median one on ventral surface. Female with 2 reclinate frontoorbitals.

Ground color of thorax chiefly black, that of notopleura, humeri, scutellum, and propleura, however, yellow; pollen of mesonotum, scutellum, and upper parts of pleura yellow, that of rest of pleura whitish; inner vitta of mesonotum about as broad as diameter of trichopore of a dorsocentral bristle. Hairs of mesonotum, seutellum, and upper parts of humeri coarse, black, those of lower parts of humeri and pleura rather fine, yellowish. Hind presutural acrostical much stronger than fore one. Legs mainly yellow; hind femur brownish near apex; hind tibia blackish; all tarsi black; coxae whitish pollinose, legs otherwise without pollen; hairs of coxae and a few near base on 
posteroventral surface of hind femur yellowish, legs otherwise blackhaired. Wings hyaline, with a slight grayish tinge; $R_{1}$ with setulae on stigmatal area more closely set than elsewhere. Squamae and halteres yellow.

Abdomen yellow, becoming reddish yellow toward apex, marked with black as follows: a median rounded spot and sometimes a lateral spot on each side, on tergite 1 ; a triangular median spot, reaching basal third of segment, expanded into a complete posterior band dorsally and extending over the sides ventrally, but not reaching the sternite, on tergite 2 ; a triangular median spot reaching almost to base of segment, expanded into a transverse band that occupies posterior fourth to half of tergite dorsally and extends onto the ventral surface to border broadly on the sternite, on tergite 3 ; and a posterior spot on each side that expands broadly into a posterior margin ventrally but not dorsally or tergite 4 . Some soft yellowish hair ventrally on tergite 1; abdomen otherwise with coarse black hair. Tergites shining dorsally, with scattered yellowish pollen ventrally; tergites 2 to 4 ventrally each with anterior margin of thick white pollen, which shows from dorsal view as small side spots on segments 3 and 4 . No median marginals on first two abdominal segments.

Types.-Holotype, male, Nova Teutonia, Brazil, May 25, 1939 (Fritz Plaumann), American Museum of Natural History. Allotype, female, same data. Paratypes, two females, same data but May 22 and 31, 1939, and one male, same dafa but May 31, 1939. Male and one female paratype in the United States National Museum.

GENEA AUREA, new species

Genea analis (Say) ALDRICH, Ent. News, vol. 25, pp. 211-212, 1924 (not Dexia analis Say, Journ. Acad. Nat. Sci. Philadelphia, vol. 6, p. 177, 1829).

Length, 6 to $9 \mathrm{~mm}$. Head in ground color yellow, the lateral occipital plates black on upper third or less; pollen brownish on frontalia, clear yellow on greatest area of parafrontals, whitish with a yellowish tinge elsewhere. Hairs of occiput mostly yellow; a few black hairs above; only very scattered black setulae on parafrontals and near vibrissae. No distinct outer verticals in male. Antenna yellow, third segment brownish on apical half, brown coloration more extensive dorsally and outwardly; arista yellow, brownish on its thinner part, the hairs concolorous. Haustellum cylindrical, slightly tapering apically, 0.7 to 0.75 head height; color yellowish, at base tending toward whitish in some specimens. Palpus rather robust, as thick as haustellum in female, more slender in male; normally 1.4 to 1.6 length of third antennal segment, sometimes a little shorter in the male or a little longer in the female; setulae black, a few pale hairs below at base.

Mesonotum except humeri and sides black in ground color; parts of pleura a very dilute blackish, scarcely evident; pollen of mesonotum, 
scutellum, and uppermost parts of pleura deep yellow, almost golden, remaining pollen of pleura whitish with a slight yellow tinge; inner vitta of mesonotum as broad as diameter of a trichopore of a dorsocentral bristle. Hairs of mesonotum (except notopleura), scutellum, and upper parts of humeri coarse, black; those of thorax otherwise fine, yellowish. Legs yellow, tarsi becoming brownish apically; coxae whitish pollinose, legs otherwise without pollen; coxae and posterior and posteroventral surfaces of femora chiefly whitish pilose, legs otherwise with black stiff hairs. Wings hyaline; $R_{1}$ with setulae uniformly spaced or but slightly more closely set in the stigmatal region. Squamae and halteres yellow.

Abdomen yellow; second and third segments, sometimes also first, each with a median apical black spot dorsally ; third, fourth, and sometimes second, with a small apical spot on each side; the lateral spots, in particular, however, show a tendency to disappear. Abdomen dorsally shining, ventrally with inconspicuous whitish pollen visible in an oblique light. Hairs of first segment ventrally mostly pale; those of rest of abdomen black. First segment with weak though distinct median marginals.

Types.-Holotype, male, Chain Bridge, Va., August 3, 1923 (J. M. Aldrich), U.S.N.M. No. 57292. Allotype, female, Plummers Island, Md., September 29, 1912 (P. R. Meyers). Paratypes: one female, Chain Bridge, Va., June 25, 1923 (J. M. Aldrich) ; one female, Plummers Island, Md., August 18, 1912 (J. R. Malloch); one female, Lafayette, Ind., September 9, 1916 (J. M. Aldrich) ; one female, Atlanta, Ga., June 30, 1930 (P. W. Fattig) ; one male, one female, Monticello, Fla., July 27, 1914 (A. I. Fabis), Quaintance No. 10573, "bred from T. subcanalis Walk.," August 24 and 21, 1914 [all U.S.N.M.]; one female, Manhattan, Kans., October 1924; three females, Babylon, Long Island, N. Y., June 28, 1935, and July 2, 1936 (Blanton and Borders), and June 25, 1935 (F. S. Blanton) [H. J. Reinhard Collection].

This species has been reared from Tetralopha subcanalis (Walker).

The best disposition of Dexia analis Say is to place it, as Smith ${ }^{\circ}$ suggested, among the unidentifiable species. Coquillett ${ }^{10}$ considered it a synonym of, and therefore holding priority over, his Myobia depile (=Leskiopalpus depilis (Coquillett)). Aldrich, however, disagreed with Coquillett's interpretation of Dexia analis, apparently on the strength of Say's statement that "the proboscis and palpi are much elongated."

I believe, however, that Coquillett was more probably right than Aldrich. Say's description, in part, reads "proboscis black, yellow at tip; thorax black, with a somewhat golden reflection; a dull

${ }^{\circ}$ Proc. Ent. Soc. Washington, vol. 19, p. $125,1917$.

10 U. S. Dept. Agr., Div. Ent., Tech. Bull. 7, p. 67, 1897. 
yellow line on each side, passing over the origin of the wings ... abdomen pale yellow, tips fuscous." The coloration of the proboscis agrees with that of Leskiomima depilis and sharply disagrees with that of Genea aurea. Under low magnification the thorax of L. depilis might well be seen as Say described it, and the abdomen tends to be darkened at the apex; in G. aurea, on the other hand, the heavily dusted thorax, with its paler ground color, would hardly appear that way, and the abdomen is yellow, with median posterior spots on the individual segments. Moreover, in L. depilis the palpi are decidedly elongated in comparison with those of Dexia vertebrata Say (Zelia vertebrata (Say) ) described in the same paper as $D$. analis. At best, some element of doubt concerning the identity of Say's species remains, and since this can never be resolved by examination of a type specimen, it is best to let Coquillett's species, of the identity of which we can be positive, remain.

\section{GENEA TRIFARIA (Wiedemann)}

Stomoxys trifaria Wiedemann, Analecta Ent., p. 41, 1824; Aussereuropaische zweiflügelige Insecten, vol. 1, pp. 250-251, 1830.

Genea maculiventris Rondani. Nuovi Aun. Sci. Nat. Bologna, ser. 3, vol. 2, pp. 173-174, 1850.-ALdRIch, Proc. U. S. Nat. Mus., vol. 74, p. 13, 1929.Townsend, Rev. Ent., vol. 1, p. 90, 1931 (synonymy).

Genea trifaria (Wiedemann) Townsend, Rev. Ent., vol. 1, p. 90, 1931.

Length, 6 to $7 \mathrm{~mm}$. Head in ground color yellow except lateral occipital plates, which are blackish on approximately upper half; pollen brownish on frontalia, yellowish on larger part of parafrontals, and whitish with a yellowish tinge elsewhere. Parafrontals bare or with a very few black hairs; pile of occiput concolorous with ground color, the pale pile being of fine texture. Outer verticals weak in male. Antenna yellow, third segment infuscated except on basal two-fifths ventrally and inwardly; arista yellow, darkened on thinner part, the hairs concolorous. Haustellum 1.1 to 1.3 head height, cylindrical on basal half, then suddenly constricted, the apical part slightly though distinctly bowed backward; color yellow, apical half blackish above, the setulae on that part arising from pigmented pores. Palpus 1.7 to 1.9 length of third antennal segment, as robust as haustellum in female, somewhat more slender in male.

Mesonotum, except humeri and sides, and certain pleural areas of variable extent blackish in ground color; pollen of mesonotum, humeri, and uppermost parts of pleura yellowish, that of remaining parts of pleura whitish; inner vitta of mesonotum as wide as diameter of a trichopore of a dorsocentral bristle. Pile of mesonotum, scutellum, and upper parts of humeri black, of lower parts of humeri and of pleura whitish. Legs yellow, tarsi blackish; coxae whitish pollinose, 
legs otherwise without pollen; some whitish hairs on coxae and at base of posteroventral surface of femora, legs otherwise black-haired. Wings hyaline; setulae of vein $R_{1}$ more closely set toward apex of vein. Squamae and halteres yellow. Abdomen yellow to yellowish orange; second and third segments, sometimes also first, each with a triangular median apical black spot dorsally; third and fourth, and usually second, segments each with a small apical spot on each side; abdomen wholly shining dorsally, the basal two tergites ventrally with thin whitish pollen visible only in an oblique light. Segment 1 ventrally mostly white-pilose; pile of abdomen otherwise black.

Types.-The type of S. trifaria, a male labeled "ex Amer: m: Schmidt," was still extant in the University Zoological Museum, Copenhagen, in 1928, when it was examined by Townsend. G. maculiventris was described from a male from Venezuela in the Museo Torinese; Townsend apparently erred in regard both to the sex and location of the type in his twice-published statement, "female $\mathrm{Ht}$ in Bologna."

The above description was based on one female, "Piedra B.," 11 April; two females, Cano Saddle, Gatun Lake, Panama, May 3 and June 1923 (R. C. Shannon); one female, San Esteban, Venezuela, November 1939 (Pablo Anduze) [all U.S.N.M.]; one male, Sangrelaya, Honduras, April 13, 1924 (C. H. Curran) ; and 1 male, Corocito, Honduras, April 3, 1924 (C. H. Curran) [Amer. Mus. Nat. Hist.].

GENEA GLOSSATA (Townsend), new combination

Geneoglossa glossata Townsend, Rev. Ent., vol. 5, p. 225, 1935.

I can find no significant difference between this species and $G$. trifaria except in the greater length of the haustellum in relation to the head (ratio, 1.6 in type female, 1.5 in two males). The ratio between the length of the palpus and that of the third antennal segment is 1.9 for the female and 2.0 for the males. The two species may be synonymous, but the insufficiency of the material at hand does not at present justify drawing such a conclusion.

Holotype.-Female, Tapera, Pernambuco, Brazil, October 20, 1932, U.S.N.M. No. 57293.

I have also seen a male, Tapera, Pernambuco, September 11, 1935, and a male, "Utingo," May 24, on foliage (Townsend Collection).

\footnotetext{
11 According to the editor's footnote in Aldrich, Ent. News, vol. 35, p. 211, 1924, this locality is probably Piedra Blanca, Bolivia, 4 miles west of Corumba, Brazil.
} 


\section{$2 \mathrm{BHL}$ Biodiversity Heritage Library}

1947. "A review of the Larvaevorid flies of the tribe Leskiini with the setulose first vein $\left(\mathrm{R}_{\imath}\right)$." Proceedings of the United States National Museum 97, 91-115.

View This Item Online: https://www.biodiversitylibrary.org/item/53540

Permalink: https://www.biodiversitylibrary.org/partpdf/52633

\section{Holding Institution}

Smithsonian Libraries

\section{Sponsored by}

Smithsonian

\section{Copyright \& Reuse}

Copyright Status: Public domain. The BHL considers that this work is no longer under copyright protection.

This document was created from content at the Biodiversity Heritage Library, the world's largest open access digital library for biodiversity literature and archives. Visit BHL at https://www.biodiversitylibrary.org. 